\title{
Identification of Restriction Fragments from Two Cryptic Clostridium butyricum Plasmids That Promote the Establishment of a Replication-defective Plasmid in Bacillus subtilis
}

\author{
By MARGARET E. COLLINS, JOHN D. OULTRAM AND \\ MICHAEL YOUNG* \\ Department of Botany and Microbiology, University College of Wales, Aberystwyth, \\ Dyfed SY23 3DA, UK
}

(Received 26 July 1984 ; revised 13 February 1985)

\begin{abstract}
Clostridium butyricum NCIB 7423 carries two cryptic plasmids, pCB101 (6.05 kbp) and pCB102 $(7.8 \mathrm{kbp})$. Sites for the restriction enzymes EcoRI, EcoRV, HindIII, ClaI and Pst I have been found in one or both of these plasmids and their relative positions determined. Restriction fragments from both plasmids have been inserted into a vector plasmid (pJAB1) that is able to replicate in Escherichia coli but not in Bacillus subtilis and the recombinant plasmids have been established in $E$. coli. A $3.3 \mathrm{kbp}$ Sau3A fragment of pCB101 conferred upon the vector the ability to transform both $\mathrm{Rec}^{+}$and $\mathrm{Rec}^{-}$strains of $B$. subtilis. Plasmid $\mathrm{pRB} 1$, a representative chimaera carrying only the $3.3 \mathrm{kbp}$ Sau $3 \mathrm{~A}$ fragment of pCB101, was successfully transferred from $B$. subtilis back to $E$. coli. Plasmid pRB1 was readily lost from $B$. subtilis in the absence of selection. This evidence, together with the results of hybridization experiments, suggests that pRB1 is present as a weakly replicating autonomous element in $B$. subtilis. A recombinant plasmid carrying a $2.0 \mathrm{kbp}$ Sau3A fragment of pCB 102 underwent integration into the $B$. subtilis chromosome.
\end{abstract}

\section{INTRODUCTION}

The presence of two cryptic plasmids in Clostridium butyricum NCIB 7423 has previously been reported (Minton \& Morris, 1981). The plasmids, pCB101 and pCB102, are relatively small (5.6 and $7.4 \mathrm{kbp}$, respectively) and are stably maintained apparently in the absence of any selective pressures. These features suggest that the plasmids could form the basis of suitable cloning vectors for use in clostridia once methods for DNA transfer to these organisms have been developed.

Here we report the results of a detailed restriction analysis of $\mathrm{pCB} 101$ and $\mathrm{pCB} 102$ and the cloning of restriction fragments from both of these plasmids in Escherichia coli and Bacillus subtilis. The results suggest that the sizes of the two plasmids are slightly greater than was previously thought $(6.05 \mathrm{kbp}$ and $7.8 \mathrm{kbp})$. It appears that the replication origin of $\mathrm{pCB} 101$ functions weakly in $B$. subtilis.

\section{METHODS}

Organisms. Clostridium butyricum NCIB 7423, which produces the bacteriocin butyricin 7423, was a laboratory stock strain. Bacillus subtilis strain 168 trpC2 is a laboratory wild-type, and strain GSY908 argC4 hisAl recE4 was obtained from C. Anagnostopoulos (Centre de Génétique Moléculaire, CNRS, Gif-sur-Yvette, France). Strain SA120 trpC2 spoIIE : : cat harbours the integrational plasmid pPAT83. Upon transformation of $\mathrm{Spo}^{+}$strains of $B$. subtilis the plasmid integrates into and insertionally inactivates the spoIIE locus (M. Young, unpublished results). The strain CA 160 of Escherichia coli that was used as recipient in transformations was a $r_{\bar{K}} \mathrm{~m}_{\bar{K}}$ recBC derivative of E. coli $\mathrm{C} 600$ thi-1 thr-1 leu-6 lacY ton azi supE44. E. coli strain SL2034, a transformable Dam ${ }^{-}$strain whose origin is obscure (Piggot et al., 1984), was used for the propagation of plasmid pJAB1. 
Plasmids. The two cryptic plasmids pCB101 and pCB102 were present in C. butyricum NCIB 7423 (Minton \& Morris, 1981).

Plasmid pJAB 1 was constructed by M. Sargent and J. Brannigan by ligating together fragments of the positive cloning vector pTR262 (Roberts et al., 1980) and pJH101 (Ferrari et al., 1983) after they had been digested with AvaI and PstI (Sargent \& Bennett, 1985). Plasmid pJAB1 comprises the segment of pTR262 that contains the $\lambda c \mathrm{I}$ gene together with the pBR322 tetracycline-resistance gene and the segment of pJH101 that contains the pC194derived chloramphenicol-resistance gene (see Fig. 2). The chloramphenicol-resistance gene is expressed in both $E$. coli and $B$. subtilis, but the plasmid can only replicate in the former host. Insertion of foreign DNA at the unique $B c l I$ or HindIII sites inactivates the $\lambda c I$ gene and allows expression of tetracycline-resistance. The enzyme $B c l$ i is sensitive to the dam methylation system of $E$. coli and therefore $\mathrm{pJABI}$ was maintained in and prepared from a Dam$^{-}$strain of $E$. coli (SL2034).

Plasmid pHV33 has been described by Primrose \& Ehrlich (1981).

Growth of organisms. C. butyricum NCIB 7423 was maintained by growth on Reinforced Clostridial Medium (Oxoid or Lab M) which was solidified by the addition of $1.5 \%(w / v)$, agar. The cultures were incubated anaerobically at $37^{\circ} \mathrm{C}$ and induced to form spores by exposure to air. Sporulated cultures were stored aerobically at room temperature. E. coli strains were grown aerobically at $37^{\circ} \mathrm{C}$ in LB medium (containing, per litre: tryptone, $10 \mathrm{~g}$; yeast extract, $5 \mathrm{~g} ; \mathrm{NaCl}, 10 \mathrm{~g}$ ) or on $\mathrm{LB}$ medium solidified with $1.5 \%$ agar. Antibiotics (chloramphenicol and tetracycline) were added to the media as required to a final concentration of $20 \mu \mathrm{g} \mathrm{ml}^{-1}$. B. subtilis strains were grown with good aeration at $37^{\circ} \mathrm{C}$ in liquid cultures of Penassay broth (Difco) or Brain Heart Infusion Broth (Difco). The solid medium used for growth of $B$. subtilis contained, per litre: nutrient broth, $13 \mathrm{~g} ;$ agar, $15 \mathrm{~g} ; 1 \mathrm{ml}$ salts solution $\mathrm{A}$ (which contained, per litre: $\mathrm{FeCl}_{3} .6 \mathrm{H}_{2} \mathrm{O}, 0.98 \mathrm{~g} ; \mathrm{MgCl}_{2} .6 \mathrm{H}_{2} \mathrm{O}, 8 \cdot 3 \mathrm{~g} ; \mathrm{MnCl}_{2} .4 \mathrm{H}_{2} \mathrm{O}, 19 \cdot 79 \mathrm{~g}$ ) and $10 \mathrm{ml}$ salts solution $\mathrm{B}$ (which contained, per litre: $\mathrm{NH}_{4} \mathrm{Cl}, 53.5 \mathrm{~g} ; \mathrm{Na}_{2} \mathrm{SO}_{4}, 10.6 \mathrm{~g} ; \mathrm{KH}_{2} \mathrm{PO}_{4}, 6.8 \mathrm{~g} ; \mathrm{NH}_{4} \mathrm{NO}_{3}$, $9.7 \mathrm{~g} ; \mathrm{pH} 7 \cdot 0)$. Chloramphenicol $\left(5 \mu \mathrm{g} \mathrm{ml}^{-1}\right)$ was added as appropriate.

Extraction of DNA. Plasmids pCB101 and pCB102 were extracted from C. butyricum after the growth of organisms in CY medium containing, per litre: glucose, $20 \mathrm{~g} ; \mathrm{NH}_{4} \mathrm{Cl}, 3 \mathrm{~g} ; \mathrm{CaCl}_{2} .6 \mathrm{H}_{2} \mathrm{O}, 0 \cdot 1 \mathrm{~g}$; yeast extract, $3 \mathrm{~g}$; L-cysteine. $\mathrm{HCl}, 0.5 \mathrm{~g}$; p-aminobenzoic acid, $100 \mu \mathrm{g}$; biotin, $10 \mu \mathrm{g}$; plus $10 \mathrm{ml}$ of a trace elements solution, which was essentially as described by Vishniac \& Santer (1957) except that the concentration of $\mathrm{ZnSO}_{4} .7 \mathrm{H}_{2} \mathrm{O}$ was reduced from 22 to $2 \cdot 2 \mathrm{~g} \mathrm{l}^{-1}$. Casamino acids $(10 \mathrm{ml}$ of a $10 \%$, w/v, solution) and potassium phosphate $(50 \mathrm{ml}$ of a $1 \mathrm{M}$ solution, $\mathrm{pH} 7.0$ ) were added as sterile solutions after autoclaving. The method described by Minton \& Morris (1981) was used to lyse the bacteria, except that the lysing solution contained, in addition, $0.5 \% \mathrm{Brij}-58$. After lysis, RNA was removed by incubation at $37^{\circ} \mathrm{C}$ for $1 \mathrm{~h}$ with RNAase $\left(20 \mu \mathrm{g} \mathrm{ml}^{-1}\right.$, pre-heated to $80^{\circ} \mathrm{C}$ for $\left.10 \mathrm{~min}\right)$. The lysate was deproteinized by extraction with $1 \mathrm{vol}$. phenol/chloroform $(1: 1, \mathrm{v} / \mathrm{v})$ followed by 2 vols chloroform/isoamyl alcohol $(24: 1, \mathrm{v} / \mathrm{v})$ and dialysed overnight against 5 litres $10 \mathrm{mM}$-Tris/HCl, $\mathrm{pH} 8 \cdot 0$, containing $0.1 \mathrm{mM}-\mathrm{Na}_{2}$ EDTA. DNA was precipitated by the addition of 2 vols chilled $95 \%(\mathrm{v} / \mathrm{v})$ ethanol and the mixture was held at $-20^{\circ} \mathrm{C}$ for several hours. The DNA was then collected by centrifugation and redissolved in $15-20 \mathrm{ml}$ $10 \mathrm{~mm}-\mathrm{Tris} / \mathrm{HCl}, \mathrm{pH} 8 \cdot 0$, containing $0 \cdot 1 \mathrm{~mm}-\mathrm{EDTA}$, before $\mathrm{CsCl}$ density gradient centrifugation.

Large scale plasmid extraction from $E$. coli was done by established methods. A cleared lysate was prepared according to the method of Clewell \& Helinski (1969) and plasmid DNA was purified by two cycles of CsCl density gradient centrifugation in the presence of ethidium bromide. Plasmids were routinely amplified by the addition of spectinomycin $\left(300 \mu \mathrm{g} \mathrm{ml}^{-1}\right)$ to late exponential phase cultures.

The large scale extraction of both chromosomal and plasmid DNA from $B$. subtilis was carried out essentially as described by Gryczan et al. (1978) except that after low speed centrifugation, nucleic acid was precipitated by the addition of PEG 6000 to a final concentration of $10 \%(\mathrm{w} / \mathrm{v})$. After holding the mixture at $4{ }^{\circ} \mathrm{C}$ for $1 \mathrm{~h}$ the nucleic acid was collected by centrifugation and redissolved in $10 \mathrm{~mm}$-Tris/ $\mathrm{HCl}$, containing $1 \mathrm{~mm}$-EDTA, pH 8.0, before $\mathrm{CsCl}$ density gradient centrifugation.

Two methods were used to extract plasmids on a small scale from $1 \mathrm{ml}$ volumes of culture: the method of Holmes \& Quigley (1981) was used for E. coli strains and the method of Birnboim \& Doly (1979) for B. subtilis strains.

Restriction and ligation of DNA. Restriction enzymes were purchased from Bethesda Research Laboratories (BamHI, ClaI, EcoRI, HindIII, PstI, SalI, Sau3A and XhoI), Cambridge Biotechnology Laboratories (BclI and $S m a \mathrm{I}$ ) and Boehringer ( $E c o \mathrm{RV}, P v u \mathrm{II}$ and $\mathrm{XbaI}$ ). They were used according to the manufacturer's instructions. To ensure complete digestion of chromosomal DNA samples a tenfold excess of enzyme was used; half of the enzyme was added initially, and the remainder was added 60 min later. $T_{4}$ DNA ligase was also supplied by Boehringer.

Construction of recombinant plasmids. A DNA sample $(3 \mu \mathrm{g})$ containing a mixture of pCB101 and pCB102 was digested to completion with HindIII and a separate sample $(3 \mu \mathrm{g})$ was partially digested with Sau3A. The restriction fragments thus obtained were mixed with an equal quantity of $\mathrm{pJAB} 1$ that had been cleaved with either $H$ indIII or $B c l$ I. The DNA mixture was heated to $55^{\circ} \mathrm{C}$ and allowed to cool slowly. After ligation overnight at $4{ }^{\circ} \mathrm{C}$ the samples were used to transform $E$. coli CA160; selection was made for tetracycline-resistant transformants.

Agarose gel electrophoresis. DNA samples were subjected to electrophoresis in horizontal $0 \cdot 6-1.5 \%(w / v)$ agarose gels (Sigma) in TEB buffer (which contained, per litre: Tris base, $10.8 \mathrm{~g}$; EDTA, $0.93 \mathrm{~g}$; boric acid, $5 \cdot 5 \mathrm{~g}$ ). Before 
applying samples to the gel they were mixed with $10 \%$ of their volume of tracking dye (glycerol, $50 \%, \mathrm{v} / \mathrm{v}$; $\mathrm{Na}_{2}$ EDTA, $50 \mathrm{~mm}$; bromophenol blue, $15 \mu \mathrm{g} \mathrm{ml}^{-1}$ ).

Transformation. E. coli CA160 was transformed with plasmid DNA after the bacteria had been permeabilized by treatment with $\mathrm{CaCl}_{2}$ and heat-shocked (Mandel \& Higa, 1970). Transformed bacteria were incubated for $90 \mathrm{~min}$ in broth before selection of tetracyline-resistant transformants on LB agar containing $20 \mu \mathrm{g}$ tetracycline $\mathrm{ml}^{-1}$.

For transformation of $B$. subtilis, competence was induced by the method of Anagnostopoulos \& Spizizen (1961). Plasmid DNA (about $0.5 \mu \mathrm{g}$ ) was incubated with $1 \mathrm{ml}$ competent cells for $90 \mathrm{~min}$ and transformants were selected on nutrient agar containing $5 \mu \mathrm{g}$ chloramphenicol $\mathrm{ml}^{-1}$.

Nick translation and Southern hybridization procedures. A sample of plasmid pJAB1 (about $0.5 \mu \mathrm{g}$ DNA) was labelled to high specific activity (about $10^{7}$ d.p.m. per $\mu$ g DNA) by nick translation (Jeffreys \& Flavell, 1977). DNA fragments for hybridizations were separated by agarose gel electrophoresis, depurinated in situ (Wahl et al., 1979) and transferred to a nitrocellulose filter (Southern, 1979). The protocol used for hybridization and washing of the filters was as described by Sager et al. (1981) except that dextran sulphate was omitted from the solutions. Autoradiography was done at $-70^{\circ} \mathrm{C}$ using pre-fogged Kodak X-omat RP3 film and an intensifying screen.

\section{RESULTS}

\section{Restriction analysis of $p C B 101$ and $p C B 102$}

The presence of both pCB101 and pCB102 in the plasmid DNA prepared from $C$. butyricum 7423 complicated analysis of the restriction data. However, since pCB101 was present at a higher concentration in the DNA preparation than was pCB102, the provenance of the restriction fragments could be inferred from the relative intensities of the bands in agarose gels stained with ethidium bromide and visualized under UV light. In several instances bands from both plasmids co-migrated (e.g. both gave rise to a fragment of about $4.5 \mathrm{kbp}$ after HindIII digestion) but these were resolved by double digestion analysis. Sites for ClaI, EcoRV, HindIII and Sau3A were found in both plasmids, while pCB102 had, in addition, sites for EcoRI and PstI. Neither plasmid was cut by the following enzymes: BamHI, BclI, BglII, SalI, SmaI, SstI, $X b a \mathrm{I}$ or $X$ hoI. Restriction maps of pCB101 and pCB102 are shown in Fig. 1 . They are based, in part, on data obtained from the analysis of recombinant plasmids containing fragments of pCB101 and pCB102, some of which are also shown in Fig. 1.

\section{Cloning fragments of $p C B 101$ and $p C B 102$ in the vector $p J A B 1$}

After partial digestion with Sau3A or complete digestion with HindIII, fragments of plasmids pCB101 and pCB102 were cloned into the BclI or HindIII sites of pJAB1 as described in Methods. Twelve tetracycline-resistant transformants carrying Sau3A fragments and eighteen tetracycline-resistant transformants carrying HindIII fragments were picked for further analysis. After they had been purified by streaking for single colonies on LB agar + tetracycline, plasmid DNA was extracted from each isolate by the method of Holmes \& Quigley (1981). Recombinant plasmids carrying Sau3A and HindIII fragments were denoted pRB1-12 and pRJ1-18, respectively. They were initially characterized using the same enzyme as had been used in their construction. This revealed that all of the HindIII and Sau3A fragments of pCB101 (the more abundant plasmid) had been cloned successfully. However, the only portion of pCB102 that had been cloned was a $2 \mathrm{kbp}$ Sau3A fragment present in pRB7.

\section{Transformation of $B$. subtilis by recombinant plasmids}

Samples of all of the recombinant plasmids were incubated with competent cells of $B$. subtilis 168 and selection was made for chloramphenicol-resistant transformants. The vector plasmid pJAB1 cannot transform $B$. subtilis to chloramphenicol-resistance since it lacks a functional replication origin for this organism. None of the pRJ plasmids (carrying HindIII fragments of pCB101) gave transformants of $B$. subtilis, whereas several of the pRB plasmids did transform $B$. subtilis to chloramphenicol-resistance (Table 1). These plasmids included $\mathrm{pRB} 7$, which carried a $2 \mathrm{kbp}$ Sau3A fragment from pCB102, and two other isolates (pRB1 and pRB5), which had in common a $3.3 \mathrm{kbp} \mathrm{Sau3A}$ fragment from pCB101 (Fig. 1). None of the pRB plasmids that failed to transform $B$. subtilis harboured either of these fragments. 

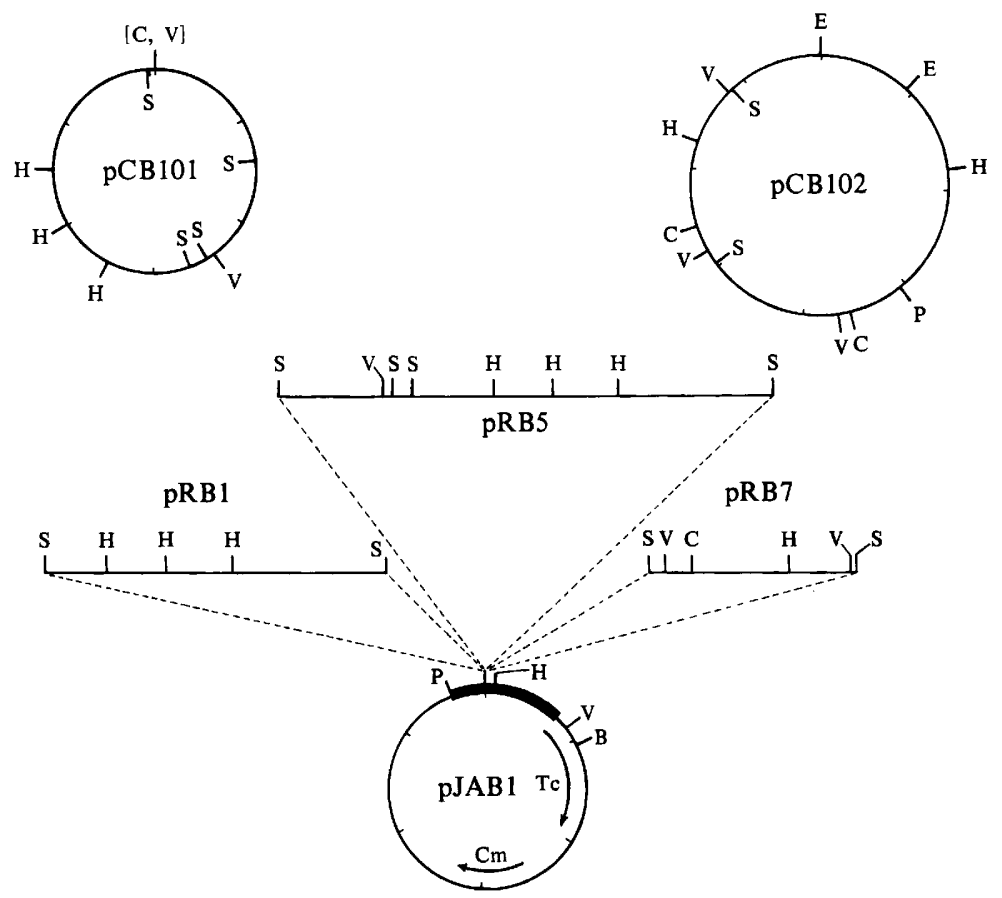

Fig. 1. Restriction maps of plasmids $\mathrm{pCB} 101$ and $\mathrm{pCB} 102$ and three recombinant plasmids, pRB 1,5 and 7. The recombinant plasmids carry Sau3A fragments of pCB101 (pRB1 and 5) or pCB102 (pRB7) inserted at the $B c l l$ site of the vector pJAB1. Plasmid pCB102 has several Sau3A sites in addition to the two that are shown. The approximate extent of $\lambda$ DNA sequences in $\mathrm{pJAB} 1$ is indicated by the bold line. The sizes of the various plasmids are pCB101, 6.05 kbp; pCB102, 7.8 kbp; pJAB1, 5.8 kbp; pRB1, $9 \cdot 1 \mathrm{kbp} ; \mathrm{pRB} 5,10 \cdot 3 \mathrm{kbp}$; pRB7, $7 \cdot 8 \mathrm{kbp}$. Sites for the following restriction endonucleases are shown: BamHI, B; ClaI, C; EcoRI, E; HindIII, H; PstI, P;Sau3A, S;EcoRV, V.

Table 1. Transformation of $B$. subtilis 168 and GSY908 with recombinant plasmids

\begin{tabular}{|c|c|c|c|}
\hline \multirow[b]{3}{*}{ Plasmid } & \multirow{3}{*}{$\begin{array}{c}\text { Fragments of } \\
\text { pCB101 present* }\end{array}$} & \multicolumn{2}{|c|}{ No. of transformants $\dagger$} \\
\hline & & \multicolumn{2}{|c|}{ Recipient: } \\
\hline & & $168\left(\operatorname{Rec}^{+}\right)$ & GSY908 $\left(\mathrm{Rec}^{-}\right)$ \\
\hline pJAB1 & None & $\mathbf{0}$ & ND \\
\hline pHV33 & None & 1810 & 305 \\
\hline pRJ 1 and 2 & HindIII 0.6 & 0 & ND \\
\hline pRJ6, 9,10 and 13 & HindIII 4.95 & 0 & ND \\
\hline pRJ14 & HindIII $0.5+0.6$ & 0 & ND \\
\hline pRB 1 & Sau 3 A 3.3 & 550 & 110 \\
\hline pRB2 & Sau3A 0.25 & 0 & ND \\
\hline pRB5 & Sau 3 A $3.3+1 \cdot 1+0.25$ & 1280 & 20 \\
\hline pRB $7 \ddagger$ & Sau3A $2 \cdot 0_{+}^{+}$ & 28 & 0 \\
\hline pRB 8 & Sau $3 \mathrm{~A} 1 \cdot 1$ & 7 & ND \\
\hline pRB9, 10 & Sau $3 \mathrm{~A} 1.4+1.1$ & 0,2 & ND \\
\hline $\mathrm{pRB} 12$ & Sau3A $1 \cdot 1$ & 5 & ND \\
\hline
\end{tabular}

* The fragments are identified by their sizes $(\mathrm{kbp})$.

+ Values given are the numbers of chloramphenicol-resistant transformants obtained per ml culture using as donor, plasmid DNA extracted from $1 \mathrm{ml}$ cultures, according to the method of Holmes \& Quigley (1981). The data for strains 168 and GSY908 are from separate experiments. Plasmid DNA purified by CsCl/ethidium bromide density gradient centrifugation gave the following transformation efficiencies using $B$. subtilis 168 as recipient: pRB1, $1.9 \times 10^{4} ;$ pRB5, $1.4 \times 10^{4} ; \mathrm{pRB} 7,7.5 \times 10^{1}$ (numbers of transformants per $\mu \mathrm{g}$ DNA). ND, Not determined.

$\ddagger$ The $2.0 \mathrm{kbp}$ Sau3A fragment present in pRB7 comes from pCB102 (see text and Fig. 1). 
Table 2. Segregation of chloramphenicol-sensitive bacteria from strains of B. subtilis 168 harbouring recombinant plasmids

\begin{tabular}{lccc}
\multicolumn{1}{c}{ Strain } & $\begin{array}{c}\text { No. of } \\
\text { generations* }\end{array}$ & $\begin{array}{c}\text { No. of } \\
\text { colonies tested }\end{array}$ & $\begin{array}{c}\text { Percentage of } \\
\mathrm{Cm}^{\mathrm{R}} \text { colonies }\end{array}$ \\
168(pHV33) & 21 & 150 & 73 \\
SA120(pPAT83) & 22 & 46 & 100 \\
168(pRB1) & 23 & 58 & 0 \\
168(pRB7) & 24 & 56 & 100
\end{tabular}

* Bacteria were grown in Penassay broth without chloramphenicol.

The recombinant plasmids that showed appreciable transforming activity with $B$. subtilis 168 $\left(\mathrm{Rec}^{+}\right)$as recipient were used on several different occasions to transform strain GSY908 (Rec $\left.{ }^{-}\right)$. Data from a representative experiment are given in Table 1. Chloramphenicol-resistant transformants were consistently obtained, albeit at a reduced frequency, with plasmids $\mathrm{pRB} 1$ and pRB5. In contrast, plasmid pRB7 never yielded any transformants. Plasmid pHV33, which was used as a control in these experiments, transformed both $\mathrm{Rec}^{+}$and $\mathrm{Rec}^{-}$recipients.

\section{Stability of recombinant plasmids in B. subtilis}

Strains of $B$. subtilis 168 that had been transformed with plasmids pRB1 and pRB7 were grown in the absence of chloramphenicol for more than 20 generations. Strains of $B$. subtilis harbouring pHV33 (autonomous) and pPAT83 (integrated into the spoIIE region of the chromosome - see Methods) were used as controls. Colonies that were obtained after plating suitably diluted samples of each culture on nutrient agar were then tested for their ability to grow on nutrient agar supplemented with chloramphenicol. The results (Table 2) indicate that chloramphenicol-resistance was stably maintained in the absence of selective pressure in strains 168(pRB7) and SA120(pPAT83), whereas it was lost from strain 168(pRB1) even more rapidly than from strain $168(\mathrm{pHV} 33)$.

\section{Analysis of strains of B. subtilis harbouring recombinant plasmids by Southern hybridization}

DNA samples from $B$. subtilis strains transformed with $\mathrm{pRB} 1$ and $\mathrm{pRB}$ 7 were digested with $P s t$ and either BamHI or EcoRV. The fragments produced were separated electrophoretically according to their size and transferred to a nitrocellulose filter. A nick-translated sample of pJAB1 DNA was used as hybridization probe. Both of the $\mathrm{pRB}$ plasmids have a single site for these three enzymes within the vector (pJABl) sequences (see Fig. 1). Any free plasmid DNA in the preparations would therefore give rise to a single band of hybridization corresponding to the linearized plasmid. Alternatively, if the cloned DNA fragments enabled the recombinant plasmids to integrate into the bacterial chromosome then this should result in the appearance of two bands of hybridization. The integration of more than one copy of the recombinant plasmids would generate three hybridizing fragments, one corresponding to the linear plasmid and the other two representing the border fragments (Young, 1984).

The results of the hybridization with strain 168(pRB7) are shown in Fig. 2(a). Hybridization occurred to high molecular weight DNA in the undigested sample (lane 3). After digestion with either BamHI or PstI hybridization occurred to three DNA fragments. The most intense hybridization occurred to a fragment corresponding in size to the linear plasmid (lanes 2 and 4 ). There was weaker hybridization to the other two fragments, which were most readily visible in the Pst I-digested sample, where their sizes were about 3.7 and $10.5 \mathrm{kbp}$ (lane 4).

DNA samples from six independently isolated strains of $B$. subtilis 168 harbouring pRB1 [strains 168(pRB1)a-f] were analysed after digestion with $P$ st I and $E c o R V$; the results from two representative isolates are given in Fig. 2(b). Digestion with either enzyme produced a single band of hybridization corresponding in size to linearized pRB1 (compare lanes 2, 4, 10 and 12 with lane 5). The two bands seen in doubly digested samples also corresponded (compare lanes 3 and 11 with lane 6). A faint band of hybridization that might be due to monomeric plasmid 


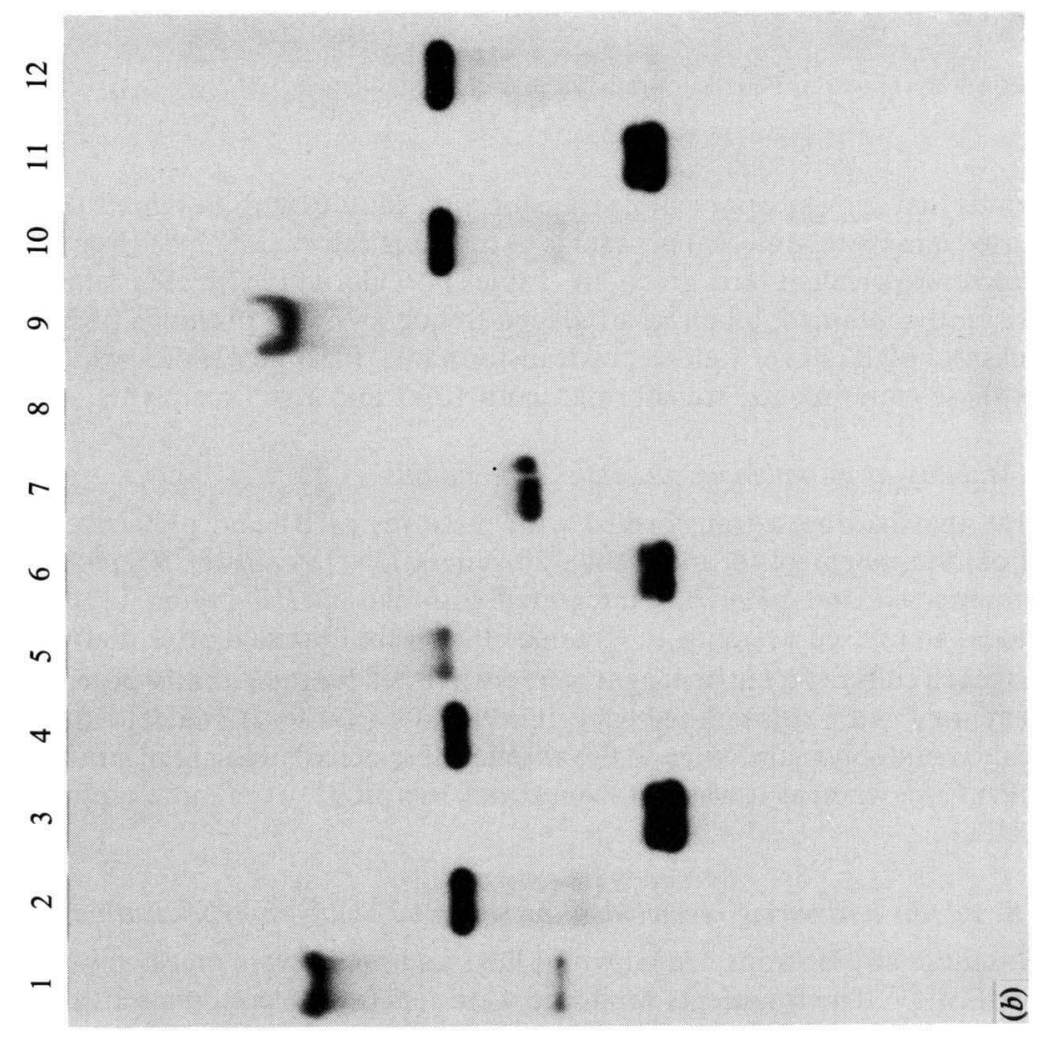

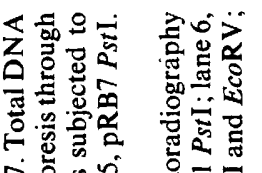

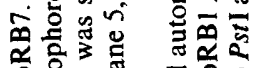

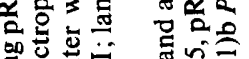

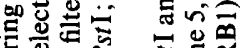

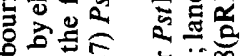

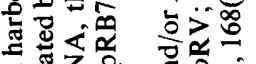
歌员 总三

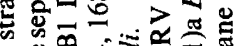

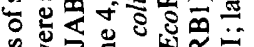

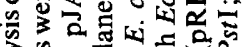

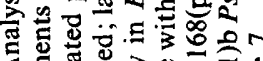

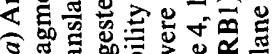

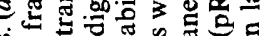

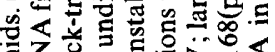

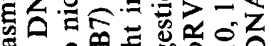

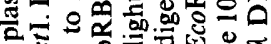

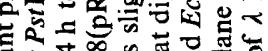

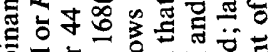

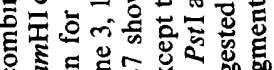

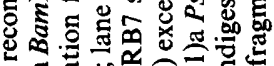

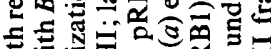

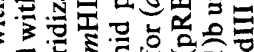

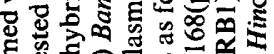

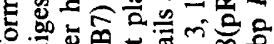

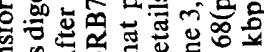

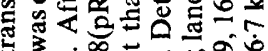

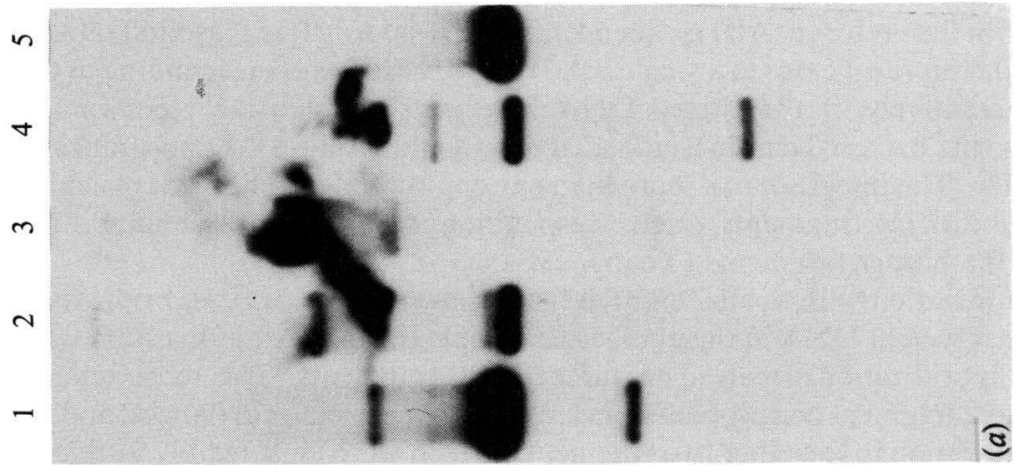

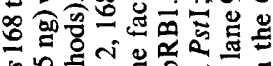
气

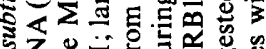

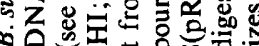

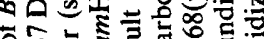

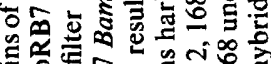

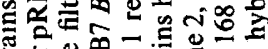
के केष

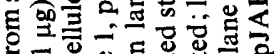

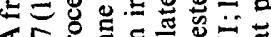

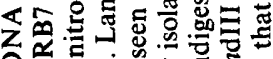

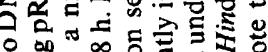

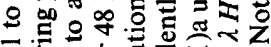

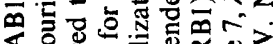

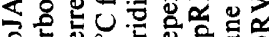

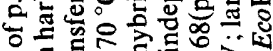
을 뉸

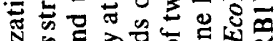
군

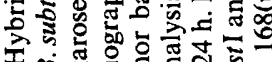

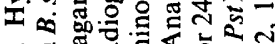

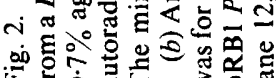



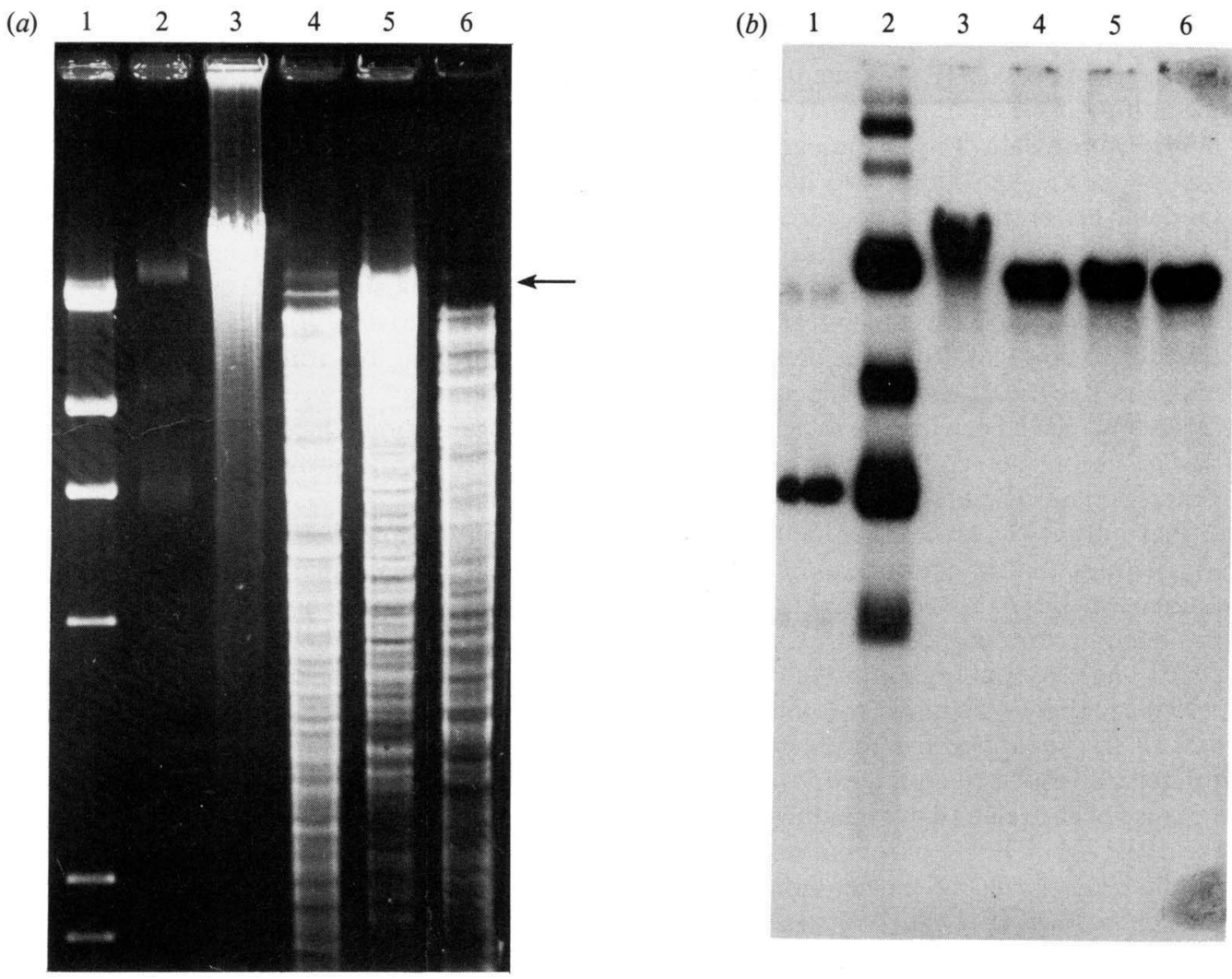

Fig. 3. Hybridization of pJABI to EcoRI-, BgllI- and ClaI-digested DNA from a strain of B. subtilis transformed with pRB1. DNA fragments generated after digestion of $1 \mu \mathrm{g}$ samples of total DNA were separated by electrophoresis through $1 \%$ agarose. Other details as for Fig. 2(b). (a) Ethidium-bromide stained electrophoretogram; (b) autoradiogram. Lane 1, $\lambda$ HindIII; lane 2, pRB1 (25 ng) undigested; lane 3, 168(pRBI)d undigested; lane 4, 168(pRB1)d EcoRI; lane 5, 168(pRBI)d BglII; lane 6, 168(PRB1)d ClaI. The arrow in (a) indicates the position of the DNA in lanes 4,5 and 6 to which intense hybridization occurred in $(b)$.

DNA is evident in the undigested DNA from one strain (lane 1), but this band was not seen in undigested DNA samples from the other five strains; hybridization occurred exclusively to high molecular weight DNA in these samples. Some further hybridizations were undertaken using DNA from one of the strains that had been digested with enzymes that do not cut $\mathrm{pRB} 1$. The gel electrophoretogram and the corresponding autoradiogram are shown in Fig. $3(a, b)$. In each case hybridization occurred almost exclusively to a band that comigrated with one of the predominant forms of pRB1 (extracted from E. coli CA160). The DNA corresponding to this hybridizing band is visible in the ethidium bromide-stained electrophoretogram (Fig. $3 a$, lanes 4 and 6).

\section{Transfer of pRBI from B. subtilis to E. coli}

Total DNA from a strain of $B$. subtilis that had been transformed with pRB1 was used to transform permeabilized cells of $E$. coli CA160. Transformants to either chloramphenicol- or tetracycline-resistance arose at a very low frequency (about 10 transformants per $\mu \mathrm{g}$ DNA). Ninety-three percent of the 69 tetracycline-resistant transformants that were obtained were also resistant to chloramphenicol, but most of the 30 chloramphenicol-resistant transformants that were obtained proved to be tetracycline-sensitive. Plasmid DNA was prepared from 11 of the doubly-resistant transformants. The DNA fragments produced after HindIII digestion were indistinguishable from those produced after digestion of $\mathrm{pRB} 1$ with the same enzyme. 


\section{DISCUSSION}

The $2.0 \mathrm{kbp}$ Sau3A fragment of pCB102 that was inserted into pJAB1 to form the recombinant plasmid $\mathrm{pRB} 7$ enabled this last plasmid to become established in $B$. subtilis. The hybridization data (Fig. 2) indicate that pRB7 was inserted into the bacterial chromosome and that under the conditions used here, more than one copy of the plasmid became integrated in tandem, i.e. amplification occurred (Young, 1984). The chromosomal location of the site of integration has not been ascertained, nor has it been determined whether integration always occurs at this particular site when the plasmid becomes established in $B$. subtilis.

In accordance with the integration of plasmid pRB7 into the $B$. subtilis chromosome, transformation was Rec-dependent (Table 1). Presumably the low transformation efficiency with the $\mathrm{Rec}^{+}$recipient is a reflection of very limited homology between donor and recipient DNA - we have been unable to detect it by Southern hybridization. Once integrated into the $B$. subtilis chromosome, the plasmid was stably maintained during growth for more than 20 generations in the absence of selection (Table 2).

Plasmid pRB1, on the other hand, appears to replicate autonomously in B. subtilis. The data in Fig. 2 are somewhat ambiguous because hybridization to high molecular weight material in the undigested DNA samples would not be expected. However, the experiment shown in Fig. 3 provided an explanation for this. After cleavage with three different enzymes that do not cut pRB1 and electrophoresis through $1 \%$ agarose, the mobility of the plasmid DNA was retarded relative to that of the linear chromosomal DNA fragments. In two cases (EcoRI and ClaI) pRB1 was clearly separated from the chromosomal DNA. In the undigested DNA sample in Fig. 3 pRB1 still tended to co-migrate with the high molecular weight chromosomal DNA, perhaps because of the relative overloading of the gel in this size range. The pattern of hybridization of the pRB1 DNA isolated from $B$. subtilis is unusual in that it does not present the appearance that might be expected of an autonomous plasmid; the DNA is almost exclusively in a single molecular form (Fig. 3).

The autonomous mode of replication of $\mathrm{pRB} 1$ in $B$. subtilis tentatively deduced from the hybridization data is supported by the ability of this plasmid, and another similar plasmid, pRB5, carrying the $3.3 \mathrm{kbp}$ Sau3A fragment of pCB101, to transform both $\mathrm{Rec}^{+}$and $\mathrm{Rec}^{-}$ strains of $B$. subtilis (Table 1). It also serves to explain the results of the segregation experiments (Table 2) which showed that $\mathrm{pRB} 1$ is rapidly lost from $B$. subtilis in the absence of selection. This may reflect weak replication of the plasmid or, alternatively, inaccurate partitioning of plasmid molecules into daughter cells at division. Finally, the autonomous mode of replication of $\mathrm{pRB} 1$ in $B$. subtilis was confirmed by transfer of the plasmid back into $E$. coli.

The plasmids constructed in the course of this investigation should prove useful in our attempts to devise techniques for protoplast-mediated transformation in C. butyricum and other saccharolytic clostridia. They are also being developed as shuttle plasmids for future use in saccharolytic clostridia and E. coli.

The financial support of the SERC in the form of a research grant from the Biotechnology Directorate is gratefully acknowledged. M.E.C. and J.D.O. were grateful recipients of SERC and SERC CASE (in conjunction with Wellcome Research Laboratories) research studentships, respectively. We thank Michael Sargent for providing us with plasmid $\mathrm{pJABl}$ and for helping us with the radioactive labelling of DNA samples by nicktranslation.

\section{REFERENCES}

Anagnostopoulos, C. \& Spizizen, J. (1961). Requirements for transformation in Bacillus subtilis. Journal of Bacteriology 81, 741-746.

BIRNBOIM, H. C. \& Doly, J. (1979). A rapid alkaline extraction procedure for screening recombinant plasmid DNA. Nucleic Acids Research 7, 1513-1523.

Clewell, D. B. \& Helinski, D. R. (1969). Supercoiled circular DNA-protein complex in Escherichia coli: purification and induced conversion to an open circular DNA form. Proceedings of the National Academy of Sciences of the United States of America 62, 1159-1166.

Ferrari, F. A., Nguyen, A., LANG, D. \& HoCh, J. A. (1983). Construction and properties of an integrable plasmid for Bacillus subtilis. Journal of Bacteriology 154, 1513-1515.

Gryczan, T. J., Contente, S. \& Dubnau, D. (1978). Characterization of Staphylococcus aureus plasmids 
introduced by transformation into Bacillus subtilis. Journal of Bacteriology 134, 318-329.

Holmes, D. S. \& Quigley, M. (1981). A rapid boiling method for the preparation of bacterial plasmids. Analytical Biochemistry 114, 193-197.

JefFreYs, A. J. \& Flavell, R. A. (1977). A physical map of the DNA regions flanking the rabbit $\beta$-globin gene. Cell 12, 429-439.

Mandel, M. \& Higa, A. (1970). Calcium-dependent bacteriophage DNA infection. Journal of Molecular Biology 53, 159-162.

Minton, N. P. \& Morris, J. G. (1981). Isolation and partial characterization of three cryptic plasmids from strains of Clostridium butyricum. Journal of General Microbiology 127, 325-331.

Piggot, P. J., Curtis, C. A. M. \& De Lencastre, H. (1984). Use of integrational plasmid vectors to demonstrate the polycistronic nature of a transcriptional unit (spoIIA) required for sporulation in Bacillus subtilis. Journal of General Microbiology 130 , 2123-2136.

Primrose, S. B. \& Ehrlich, S. D. (1981). Isolation of plasmid deletion mutants and study of their instability. Plasmid 6, 193-201.
Roberts, T. M., Swanberg, S. L., Poteete, A., Riedel, G. \& BaCKMAN, K. (1980). A plasmid cloning vehicle allowing a positive selection for inserted fragments. Gene 12, 123-127.

SAGER, R., ANISOWICZ, A. \& Howell, N. (1981). Genomic rearrangements in a mouse cell line containing integrated SV40 DNA. Cell 23, 41-50.

SARGENT, M. G. \& BenNett, M. F. (1985). Amplification of a major membrane-bound DNA sequence of Bacillus subtilis. Journal of Bacteriology 161, 589595.

SOUTHERN, E. (1979). Gel electrophoresis of restriction fragments. Methods in Enzymology 68, 152-176.

VishniaC, W. \& SANTER, M. (1957). The thiobacilli. Bacteriological Reviews 21, 195-213.

WaHL, G. M., Stern, M. \& Stark, G. R. (1979). Efficient transfer of large DNA fragments from agarose gels to diazobenzyloxymethyl-paper and rapid hybridisation by using dextran sulfate. Proceedings of the National Academy of Sciences of the United States of America 76, 3683-3687.

YouNG, M. (1984). Gene amplification in Bacillus subtilis. Journal of General Microbiology 130, 16131621. 